\title{
REVIEW
}

\section{SUBJECTIVE PERSPECTIVES OF DIABETES MELLITUS AMONG IMMIGRANTS IN THE FORMER SOVIET UNION}

\author{
Sigrun Simolka ${ }^{1,2}$, Wilfried Schnepp ${ }^{1}$ \\ ${ }^{1}$ Department of Nursing Sience, Faculty of Health, University of Witten/Herdecke, Germany \\ ${ }^{2}$ Diabetes-Schwerpunktpraxis F. Mederacke/Dr. med. F. Graupner, Chemnitz, Germany
}

Received December 4, 2016; Accepted February 20, 2017. Copyright: This is an open access article distributed under the terms of the Creative Commons Attribution International License (CC BY). http://creativecommons.org/licenses/by/4.0/

\begin{abstract}
Aim: The purpose of this study was to explore data concerning subjective theories, personal resources, and recommendations for counseling changes in people with diabetes mellitus from different Russian-speaking nationalities. Russian-speaking immigrants and Russian Germans may require a different type of diabetes education to native inhabitants. Design: A literature review of subjective theories of illness, personal resources, and recommendations for counseling was conducted. Methods: Literature published since 2009 was searched, including qualitative and quantitative studies. Data were found for Jewish and Russian-speaking immigrants with diabetes mellitus, but not for Russian Germans. The scope of the search was, therefore, widened. Literature on general loci of control, health beliefs, and diabetes education was included. Results: Seventeen articles were identified. These studies discussed health beliefs and behaviors, including externalized attribution of causes, and internalized locus of control. Homeopathic and natural therapies were generally preferred over other medications. However, socioeconomic status, level of education, and external circumstances in the country of origin were more important than differentiation by nationality. Conclusion: Therapists require knowledge of the living conditions in immigrants' country of origin to inform their provision of medical advice. Immigrants' general level of education, socioeconomic status, and previous living conditions are also important.
\end{abstract}

Keywords: Russian-speaking immigrants, Russian Germans, diabetes mellitus, health belief, health behavior, personal resources, counseling.

\section{Introduction}

31 December, 2011, 5.3\% of all foreigners living in Germany were from the successor states of the former Soviet Union (own calculation by: Statistisches Bundesamt, 2012). As the variety of nationalities is difficult to comprehend, this article focuses on the largest groups, comprising Russian Germans, and Jewish immigrants, and their family members (mainly citizens of their countries of origin).

Since 1990, about 2.5 million Russian Germans have immigrated to Germany, and have been known as "repatriates" since 1993 (Bundeszentrale für politische Bildung, 2012). The Federal Expellees Act (1953, reworded 2013) describes these repatriates as "ethnic Germans from the successor states of the former Soviet Union who have established residence in Germany by way of a special admissions procedure" (Bundesministerium der Justiz, 2013).

Corresponding author: Sigrun Simolka, DiabetesSchwerpunktpraxis Mederacke/Dr. Graupner, Flemmingstr. $2 g$, Chemnitz, Germany, email: Sigrun.Simolka@uni-wh.de
In their country of origin, these repatriates are referred to as "Russian Germans" (a transliteration of Российские немцы). Since the fall communism, Germans from Russia have also emigrated to the United States, and Canada. They refer to themselves as Germans from Russia, Volga Germans or Black Sea Germans (Stumpp et al., 1986).

Germany has ranked above the United States and Israel as an immigration destination for Jewish immigrants from the former Soviet Union since 2002 (Tempel, 2006). Initially, in an effort to revitalize Jewish communities in Germany, admissions to Germany were unlimited in terms of length of stay and number of immigrants. However, Jewish immigrants must now apply for entry according to the Residence Act (Bundesministerium des Inneren, 2009). By 2011, approximately 205,000 Jewish immigrants had settled in Germany. Immigration to Germany requires formal verification of Jewish nationality, and recorded membership of a Jewish community in Germany (Bundesamt für Migration und Flüchtlinge, 2013). The predominant countries of origin of these Jewish immigrants are the 
Russian Federation, Ukraine, Kyrgyzstan, and Kazakhstan (Bundesamt für Migration und Flüchtlinge, 2013). Accordingly, Jewish and Russian German immigrants' family members come from various nationalities of the former Soviet Union.

Epidemiological data for Russian-speaking immigrants and Russian Germans are difficult to interpret. The International Diabetes Federation reports that the prevalence of diabetes mellitus in the countries of origin of Russian-speaking immigrants ranges from $2.87 \%$ (Ukraine) to $9.74 \%$ (Russia). However, these data were reported by those countries, and may reflect the poorly developed Russian medical system. In New York state, where Russian speakers are one of the largest immigrant groups, the prevalence of diabetes among Russianspeaking immigrants aged 40 years and older was $16.9 \%(95 \%$ confidence interval, $14.6-19.3 \%$ (Hosler, Melnik, Spence, 2004). In Germany, a higher prevalence of diabetes was reported in Jewish immigrants $(6.5 \%)$ compared with native Germans (5.1\%), and ethnic German repatriates (2.5\%). However, these data were based on participants' selfreports. The significantly lower prevalence of diabetes in Russian Germans might be attributable to a significantly lower mean age (Tselmin et al., 2007).

In Germany, regulations for therapeutic options are explained in disease management programs; an inherent aspect of these regulations for diabetes mellitus is education and counseling. Training programs for German people affected by diabetes mellitus accredited by the Federal Insurance Office (Bundesversicherungsamt) have been evaluated. These programs are available in German for all insured immigrants. Dedicated therapists developed Russian language training materials, which helped with the content design, but did not clarify the psychological and pedagogical-didactic strategies required for consultations with Russian-speaking immigrants and repatriates.

\section{Aim}

Based on this knowledge gap, the present authors developed two research questions:

1. What are the subjective theories of illness, and what personal resources are available for the treatment of diabetes mellitus reported by Russianspeaking immigrants and Russian German repatriates from the former Soviet Union?

2. Consequently, what are the recommendations for diabetes mellitus counseling?
We searched for answers to these questions through an analysis of relevant national and international literature.

\section{Methods}

\section{Design}

Review - literature review.

\section{Eligibility criteria}

Selection criteria were based on the research questions. As the present authors had researched this topic for a previous publication (Simolka, 2011), the search period was limited to publications since 2009, to generate new knowledge. The selection included studies, full text articles, and book sections in English and German. Literature which was only available in Russian was excluded.

\section{Sources}

Relevant literature was systemically searched in PubMed, the Cochrane Library, the Cumulative Index to Nursing and Allied Health Literature, Deutsches Institut für medizinische Dokumentation und Information (German institute of medical documentation and information), Gesellschaft Sozialwissenschaftlicher Struktureinrichtungen (Leibnitz institute for social science), Scopus, Scirus, and Google Scholar. A manual literature search was also undertaken.

\section{Explanation of key terms}

Health beliefs, behavioral changes, and adherence to medical advice depend on underlying cognitive mechanisms. We used key terms as defined by the common-sense model of illness (Leventhal, Diefenbach, Leventhal, 1992) the theory of selfefficacy (Bandura, 1977), and social-learning theory (Rotter, 1966).

\section{Subjective theories of illness}

From a biomedical view of health, the dichotomy between the terms "health" and "disease" has failed as a way of managing chronic diseases (Antonovsky, 1997; Franke, 2008). Phenomenological models consider diseases from different perspectives, and explicitly reflect the views of the affected people, particularly with regard to the situation of immigrants (Kleinman, Benson, 2006).

\section{Self-management}

Self-management refers to the development and use of patients' own healthcare skills as an important element in the treatment of diabetes mellitus (Brod, Heurtin-Roberts, Francisco, 1992; International Diabetes Federation, 2015). Resources include internal and external resources, and capabilities that 
may support the treatment of chronic diseases (Schwarzer, 2004).

\section{Search}

The keywords used were (combined with Boolean operators AND and OR): diabetes mellitus, chronic illness, Jewish immigrants, Russian, Russianspeaking, Russian immigrants, late resettler, late repatriate, original Germans, ethnic Germans, Germans with Russian heritage, former Soviet Union, health belief, health behavior, subjective health experience, attitudes, perception, self-management, resources, education, counseling, and coping. Because of the small number of findings, both qualitative and quantitative descriptive investigations were deemed eligible for inclusion.

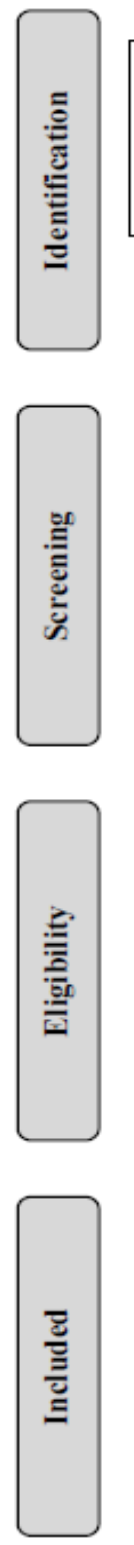

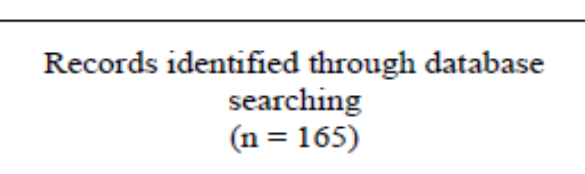

\section{Study selection and data analyses}

In total, 14 studies relating to the research questions concerning Jewish immigrants and Russian-speaking immigrants were found. As no relevant literature for Russian Germans with the above-mentioned limitations was found, the scope of the search was widened. Three studies included general information on coping with illness, personal resources, and possible recommendations regarding consultations. However, these studies did not discuss diabetes mellitus. The selection process is shown in figure 1, and was in accordance with PRISMA recommendations.

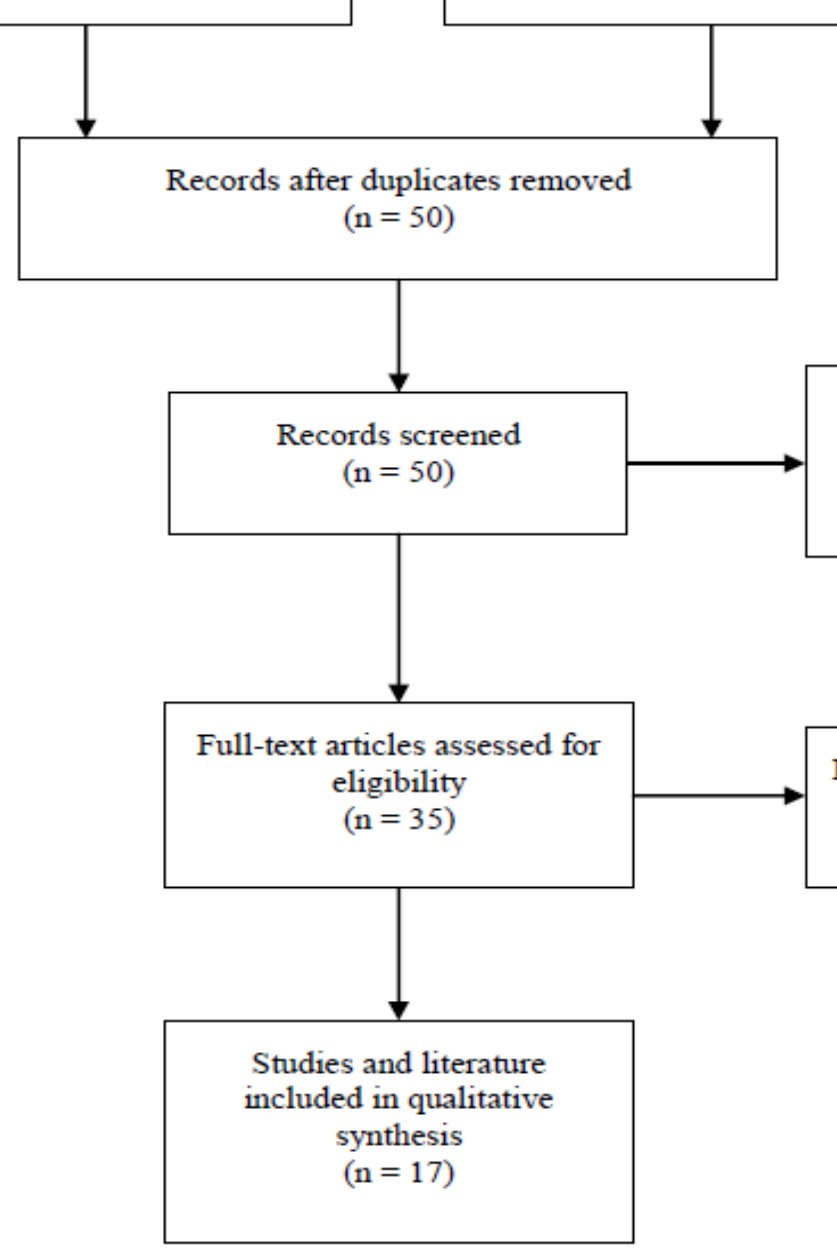

Records excluded: only abstract, only available in Russian language $(\mathrm{n}=15)$

Full-text articles excluded: no statement on the topic $(\mathrm{n}=18)$

Scheme 1 Study Flow - recommendation PRISMA 


\section{Literature appraisal criteria}

Qualitative studies were assessed using the "Enhancing transparency in reporting the synthesis of qualitative research (ENTREQ)" questionnaire (Tong et al., 2012). The ENTREQ assesses the plausibility of the scientific questions, the explanation of the qualitative design, the literature search before investigation, the description of participants, the detailed description by method of analysis, the saturation of data, and the comprehensibility of findings.

\section{Results}

Tables 1-4 present a detailed list, and description of the focus of the selected studies.

Table 1 Detailed list and description of the focus of each study: Jewish and Russian Germans with diabetes mellitus

\begin{tabular}{|c|c|c|c|c|c|c|}
\hline $\begin{array}{l}\text { Author, } \\
\text { Date }\end{array}$ & Title & Country & Publication & Methodology & Participants & $\begin{array}{l}\text { Main research } \\
\text { question }\end{array}$ \\
\hline \multicolumn{7}{|c|}{ Jewish migrants with diabetes mellitus } \\
\hline $\begin{array}{l}\text { Ben- } \\
\text { Arye et } \\
\text { al., } 2011\end{array}$ & $\begin{array}{l}\text { Exploring association of } \\
\text { spiritual perspectives } \\
\text { with complementary } \\
\text { medicine use among } \\
\text { patients with Type } 2 \\
\text { diabetes in Israel }\end{array}$ & Israel & $\begin{array}{l}\text { Ethnicity \& } \\
\text { Health }\end{array}$ & $\begin{array}{l}\text { quantitative } \\
\text { questionnaire }\end{array}$ & $\begin{array}{l}\text { reported type } 2 \\
\text { diabetes } \\
(\mathrm{n}=485)\end{array}$ & $\begin{array}{l}\text { association } \\
\text { between } \\
\text { religiosity and } \\
\text { spirituality in } \\
\text { the context of } \\
\text { complementary } \\
\text { and alternative } \\
\text { medicine }\end{array}$ \\
\hline $\begin{array}{l}\text { Simolka, } \\
2011\end{array}$ & $\begin{array}{l}\text { Diabetes mellitus bei } \\
\text { jüdischen Zuwanderern in } \\
\text { Sachsen und Sachsen- } \\
\text { Anhalt: subjektives } \\
\text { Krankheitserleben und } \\
\text { persönliche Ressourcen } \\
\text { in der } \\
\text { Krankheitsbewältigung - } \\
\text { Empfehlungen } \\
\text { hinsichtlich } \\
\text { Veränderungen der } \\
\text { Beratungssituationen }\end{array}$ & Germany & $\begin{array}{l}\text { Akademische } \\
\text { Verlagsgemeins } \\
\text { chaft }\end{array}$ & $\begin{array}{l}\text { problem- } \\
\text { focused semi- } \\
\text { structured } \\
\text { interviews, } \\
\text { qualitative } \\
\text { content analyses }\end{array}$ & $\begin{array}{l}\text { Russian- } \\
\text { speaking Jewish } \\
\text { migrants on the } \\
\text { former Soviet } \\
\text { Union }(n=18)\end{array}$ & $\begin{array}{l}\text { identifying } \\
\text { factors } \\
\text { improving } \\
\text { diabetes } \\
\text { education and } \\
\text { counselling for } \\
\text { Jewish migrants } \\
\text { with diabetes } \\
\text { mellitus }\end{array}$ \\
\hline \multicolumn{7}{|c|}{ Jewish migrants and Russian Germans with diabetes mellitus } \\
\hline $\begin{array}{l}\text { Aronson, } \\
2011 b\end{array}$ & $\begin{array}{l}\text { The salad of ideas: beliefs } \\
\text { about health and food } \\
\text { among immigrants from } \\
\text { the former USSR in } \\
\text { Germany }\end{array}$ & Germany & $\begin{array}{l}\text { Cargo, Journal } \\
\text { of Cultural and } \\
\text { Social } \\
\text { Anthropology }\end{array}$ & $\begin{array}{l}\text { qualitative } \\
\text { methodology, } \\
\text { semi-structured } \\
\text { interviews }\end{array}$ & $\begin{array}{l}\text { Russian Jewish } \\
\text { migrants } \\
\text { (arrived in the } \\
\text { 1990s) and } \\
\text { Russian } \\
\text { Germans } \\
\text { early Jewish } \\
\text { migrants } \\
\text { (arrived in the } \\
\text { 1970s) }(\mathrm{n}=24)\end{array}$ & $\begin{array}{l}\text { migrant health, } \\
\text { health beliefs, } \\
\text { conceptualizatio } \\
n \text { of the } \\
\text { relationship } \\
\text { between food, } \\
\text { migration } \\
\text { experience and } \\
\text { health }\end{array}$ \\
\hline $\begin{array}{l}\text { Aronson, } \\
2011 \mathrm{a}\end{array}$ & $\begin{array}{l}\text { Health Beliefs and Help- } \\
\text { Seeking Practices of } \\
\text { Migrants from the former } \\
\text { USSR into Germany }\end{array}$ & Germany & $\begin{array}{l}\text { The University } \\
\text { of Warwick }\end{array}$ & $\begin{array}{l}\text { qualitative } \\
\text { methodology, } \\
\text { semi-structured } \\
\text { interviews }\end{array}$ & $\begin{array}{l}\text { Russian Jewish } \\
\text { migrants and } \\
\text { Russian } \\
\text { Germans ( } \mathrm{n}= \\
27) \\
\text { medical } \\
\text { professionals, } \\
\text { employees, } \\
\text { social workers } \\
(\mathrm{n}=8)\end{array}$ & $\begin{array}{l}\text { to explore and } \\
\text { conceptualise } \\
\text { health beliefs } \\
\text { and help } \\
\text { seeking } \\
\text { behaviors }\end{array}$ \\
\hline
\end{tabular}


Table 2 Detailed list and description of the focus of each study: Russian-speaking people with diabetes mellitus

\begin{tabular}{|c|c|c|c|c|c|c|}
\hline $\begin{array}{l}\text { Author, } \\
\text { Date }\end{array}$ & Title & Country & Publication & Methodology & Participants & $\begin{array}{l}\text { Main research } \\
\text { question }\end{array}$ \\
\hline $\begin{array}{l}\text { Shultz, } \\
\text { Corbet, Allen, } \\
2009\end{array}$ & $\begin{array}{l}\text { Slavic women's } \\
\text { understanding of } \\
\text { diabetes dietary } \\
\text { self-management } \\
\text { and reported } \\
\text { dietary behaviors }\end{array}$ & USA & $\begin{array}{l}\text { Journal of } \\
\text { Immigrant and } \\
\text { Minority Health }\end{array}$ & $\begin{array}{l}\text { mixed-method } \\
\text { study: survey } \\
\text { questionnaire, } \\
\text { clinical and } \\
\text { physical } \\
\text { assessment, semi- } \\
\text { structured } \\
\text { interview }\end{array}$ & $\begin{array}{l}\text { convenience } \\
\text { sample, Slavic } \\
\text { women (Ukraine, } \\
\text { Russia, } \\
\text { Kazakhstan, other) } \\
(\mathrm{n}=10)\end{array}$ & $\begin{array}{l}\text { identify dietary } \\
\text { behaviors to } \\
\text { manage diabetes, } \\
\text { and enhance heart } \\
\text { health, describe } \\
\text { influences on } \\
\text { Slavic women's } \\
\text { dietary beliefs and } \\
\text { behaviors }\end{array}$ \\
\hline $\begin{array}{l}\text { Purath, Van } \\
\text { Son, Corbett, } \\
2011\end{array}$ & $\begin{array}{l}\text { Perceptions of } \\
\text { diabetes } \\
\text { symptoms and } \\
\text { self-management } \\
\text { strategies: a cross- } \\
\text { cultural } \\
\text { comparison }\end{array}$ & USA & $\begin{array}{l}\text { Journal of } \\
\text { Transcultural } \\
\text { Nursing }\end{array}$ & $\begin{array}{l}\text { qualitative study, } \\
\text { focus group } \\
\text { interviews }\end{array}$ & $\begin{array}{l}\begin{array}{l}\text { Slavic women } \\
(\mathrm{n}=10)\end{array} \\
\text { non-immigrant } \\
\text { white American } \\
\text { women }(\mathrm{n}=10)\end{array}$ & $\begin{array}{l}\text { to compare and } \\
\text { contrast perceived } \\
\text { symptoms of type } \\
2 \text { diabetes mellitus } \\
\text { and self- } \\
\text { management } \\
\text { strategies, Russian- } \\
\text { speaking } \\
\text { immigrant, } \\
\text { American women, } \\
\text { physical activity } \\
\text { attitudes, beliefs, } \\
\text { motivators, } \\
\text { barriers among } \\
\text { older Russian- } \\
\text { speaking } \\
\text { immigrants }\end{array}$ \\
\hline $\begin{array}{l}\text { Pasumansky, } \\
2012\end{array}$ & $\begin{array}{l}\text { Predisposition to } \\
\text { Non-Insulin- } \\
\text { Dependent } \\
\text { Diabetes Mellitus } \\
\text { Among } \\
\text { Immigrants from } \\
\text { the former Soviet } \\
\text { Union }\end{array}$ & USA & $\begin{array}{l}\text { Caring for the } \\
\text { Vulnerable - } \\
\text { Perspective in } \\
\text { Nursing Theory, } \\
\text { Practise and } \\
\text { Research }\end{array}$ & literature review & & $\begin{array}{l}\text { cultural approach, } \\
\text { preventive care } \\
\text { practise, } \\
\text { medication versus } \\
\text { remedies, } \\
\text { implications for } \\
\text { practise }\end{array}$ \\
\hline $\begin{array}{l}\text { Van Son, } \\
\text { Gileff, } \\
2013\end{array}$ & $\begin{array}{l}\text { Relying on What } \\
\text { They Know: } \\
\text { Older Slavic } \\
\text { Émigrés } \\
\text { Managing } \\
\text { Chronic Health } \\
\text { Conditions }\end{array}$ & USA & $\begin{array}{l}\text { Qualitative health } \\
\text { research }\end{array}$ & $\begin{array}{l}\text { Ethnography: } \\
\text { participant } \\
\text { observation, } \\
\text { examination, semi- } \\
\text { structured } \\
\text { interviews }\end{array}$ & $\begin{array}{l}\text { Slavic participants } \\
(\mathrm{n}=28)\end{array}$ & $\begin{array}{l}\text { shared beliefs } \\
\text { about the causes of } \\
\text { chronic conditions, } \\
\text { described } \\
\text { treatments used, } \\
\text { identified barriers } \\
\text { to care, and } \\
\text { expressed their } \\
\text { expectations of US } \\
\text { health care } \\
\text { providers }\end{array}$ \\
\hline $\begin{array}{l}\text { Van Son, } \\
2014\end{array}$ & $\begin{array}{l}\text { Developing } \\
\text { Culturally } \\
\text { Targeted Diabetes } \\
\text { Educational } \\
\text { Materials for } \\
\text { Older Russian- } \\
\text { Speaking } \\
\text { Immigrants }\end{array}$ & USA & $\begin{array}{l}\text { The Diabetes } \\
\text { educator }\end{array}$ & $\begin{array}{l}\text { description of a } \\
\text { project with } \\
\text { culturally targeted, } \\
\text { educational } \\
\text { diabetes material } \\
\text { for older Russian- } \\
\text { speaking adults }\end{array}$ & & $\begin{array}{l}\text { creation and pilot } \\
\text { testing of } \\
\text { educational } \\
\text { documents in } \\
\text { Russian language }\end{array}$ \\
\hline $\begin{array}{l}\text { Kühlbrand et } \\
\text { al., } 2014\end{array}$ & $\begin{array}{l}\text { In search of } \\
\text { patient-centred } \\
\text { care in middle } \\
\text { income countries: } \\
\text { the experience of } \\
\text { diabetes care in } \\
\text { the former Soviet } \\
\text { Union }\end{array}$ & $\begin{array}{l}\text { Armenia, } \\
\text { Belarus, } \\
\text { Moldavia, } \\
\text { Russia, } \\
\text { Ukraine }\end{array}$ & Health policy & $\begin{array}{l}\text { semi-structured } \\
\text { interviews, } \\
\text { inductive and } \\
\text { direct-deductive } \\
\text { analyses }\end{array}$ & $\begin{array}{l}\text { patient with } \\
\text { diabetes type } 1 \text { and } \\
\text { type } 2 \\
(\mathrm{n}=140) \\
\text { health care } \\
\text { provider }(\mathrm{n}=138) \\
\text { key informant } \\
(\mathrm{n}=52)\end{array}$ & $\begin{array}{l}\text { description of } \\
\text { patient-centred } \\
\text { care and access to } \\
\text { healthcare system }\end{array}$ \\
\hline
\end{tabular}




\section{Subjective theories of illness}

Franke (2008) describes the acceptance of the phenomenon of "sick" or "healthy" according to existing cultural development. A patient's locus of control with regard to health plays an important role in their adherence to, and cooperation with, therapy. An internalized belief of control means that patients expect a health event to be a consequence of their own behavior, whereas an externalized belief means they consider the result as beyond their control (Rotter, 1966).
The causal attribution of Jewish immigrants appeared to be more externalized. They considered the stress of family situations, external living conditions, the Chernobyl disaster, and the latent anti-Semitism in their country of origin as triggers for diabetes mellitus (Simolka, 2011). Therefore, diabetes mellitus was given secondary relevance and removed from their personal sphere of influence (Simolka, 2011); their life circumstances were considered worse than the disease.

Table 3 Detailed list and description of the focus of each study: Russian-speaking people (issue without diabetes but in context of chronic illness)

\begin{tabular}{|c|c|c|c|c|c|c|}
\hline $\begin{array}{l}\text { Author, } \\
\text { Date }\end{array}$ & Title & Country & Publication & Methodology & Participants & $\begin{array}{l}\text { Main research } \\
\text { question }\end{array}$ \\
\hline $\begin{array}{l}\text { Van Son, } \\
2007\end{array}$ & $\begin{array}{l}\text { Ethnomedicine } \\
\text { use by older } \\
\text { adults from a } \\
\text { Slavic } \\
\text { community (van } \\
\text { Son, 2007) }\end{array}$ & USA & $\begin{array}{l}\text { Communication } \\
\text { Nursing } \\
\text { Research }\end{array}$ & $\begin{array}{l}\text { ethnographic } \\
\text { design, } \\
\text { in-depth } \\
\text { interviews, } \\
\text { participant } \\
\text { observation, } \\
\text { constant } \\
\text { comparative } \\
\text { analyses }\end{array}$ & $\begin{array}{l}\text { Slavic older } \\
\text { adults } \\
\text { family } \\
\text { caregivers } \\
\text { key informants } \\
(\mathrm{n}=30)\end{array}$ & $\begin{array}{l}\text { understanding how } \\
\text { older Slavic } \\
\text { immigrants } \\
\text { managed their } \\
\text { chronic illness }\end{array}$ \\
\hline $\begin{array}{l}\text { Brua, Johnson, } \\
2011\end{array}$ & $\begin{array}{l}\text { Health-care } \\
\text { access in a rural } \\
\text { area: } \\
\text { perspectives } \\
\text { from Russian- } \\
\text { speaking } \\
\text { immigrants, } \\
\text { English- } \\
\text { speaking } \\
\text { doctors and } \\
\text { volunteer } \\
\text { interpreters }\end{array}$ & USA & $\begin{array}{l}\text { Pennsylvania } \\
\text { State University } \\
\text { (Doctoral } \\
\text { Thesis) }\end{array}$ & $\begin{array}{l}\text { semi- } \\
\text { structured } \\
\text { interviews, } \\
\text { analysing with } \\
\text { content } \\
\text { analyses }\end{array}$ & $\begin{array}{l}\text { Russian- } \\
\text { speaking } \\
\text { immigrants } \\
(\mathrm{n}=12) \\
\text { English- } \\
\text { speaking } \\
\text { medical staff } \\
\text { members }(\mathrm{n}=5) \\
\text { volunteer } \\
\text { interpreters } \\
(\mathrm{n}=3)\end{array}$ & $\begin{array}{l}\text { the role of } \\
\text { language as an } \\
\text { entry point or } \\
\text { impediment to } \\
\text { healthcare access, } \\
\text { the impact of } \\
\text { immigrant and } \\
\text { American } \\
\text { healthcare beliefs } \\
\text { on medical } \\
\text { behaviour }\end{array}$ \\
\hline $\begin{array}{l}\text { Van Son, } \\
\text { Stasyuk, } \\
2014\end{array}$ & $\begin{array}{l}\text { Older } \\
\text { immigrants } \\
\text { from the former } \\
\text { Soviet Union } \\
\text { and their use of } \\
\text { complementary } \\
\text { and alternative } \\
\text { medicine }\end{array}$ & USA & $\begin{array}{l}\text { Geriatric } \\
\text { Nursing }\end{array}$ & $\begin{array}{l}\text { expression of } \\
\text { opinion, } \\
\text { personal } \\
\text { clinical } \\
\text { experience }\end{array}$ & & $\begin{array}{l}\text { literature based } \\
\text { information about } \\
\text { often used } \\
\text { complementary } \\
\text { medicine and } \\
\text { remedies in Slavic } \\
\text { communities }\end{array}$ \\
\hline
\end{tabular}

A study by Van Son and Gileff (2013) reported that Russian-speaking immigrants showed little understanding of the physiological functions of their bodies. Their knowledge was unchanged from that of their ancestors. They attributed chronic diseases to externalized causes such as advanced age, serious hardship, or extreme weather conditions, and gave preference to homeopathic and herbal remedies as "God-given" therapies (Van Son, Gileff, 2013). In a literature review, Pasumansky reported that many immigrants from the former Soviet Union had experienced high psychological stress, both in their former lives and after immigration (Pasumansky, 2012). Many immigrants also considered stress to be a major risk factor for diabetes mellitus (Pasumansky, 2012).

Another study found that Russian-speaking women reported more global-holistic symptoms of diabetes than non-immigrant women (Barko et al., 2011). They described their symptoms as feelings, or an 
inability to perform activities of daily living. Compared with non-immigrants, they reported more physical complaints (e.g., back pain, tiredness, things floating in their eyes), but none of the study participants verbalized these symptoms as signs of hyper- or hypoglycemia (Barko et al., 2011).

Similarly, repatriates attributed disease to external causes, but referred to chronic diseases in general, rather than diabetes specifically. They mentioned heredity, neglect by others, and environmental causes (Wittig et al., 2003), and seemed to act on an internalized conviction of their ability to control their disease. They retained responsibility for their own treatment. Repatriates "organized" their treatment outside the usual centers in their home country, even after emigration. They divided their health conditions into "serious" illnesses that were treated by doctors, and "mild" illnesses that were treated with lay medical knowledge, often learned from their mothers (Wittig et al., 2003).

Aronson described the relationship of identity to health beliefs and help-seeking practices in her doctoral thesis (Aronson, 2011a), but did not discuss diabetes mellitus. However, she distinguished educational and socioeconomic factors and the areas of study participants' origin in her investigation of nationalities (Russian Jews or Russian Germans). She found three categories of help-seekers. First, a "privileged" [sic] group comprising urban, secondgeneration intelligentsia (most Jewish immigrants), had a broad approach and private informal networks, including highly qualified medical professionals from their parents' generation, who were able to act as institutional gatekeepers. This group's proactive health beliefs were expressed by the concepts "being cultured" and "Westernization". In terms of health behavior and practices, Westernization reflects a perception of healthy living or nutrition and high culture. Second, a "fragmentally empowered" [sic] group comprising people living in urban areas (often Russian Germans). Within one generation, this group moved from a rural to an urban setting, and achieved socioeconomic advancement. Their networks were less extensive than the privileged group, and included people with a lower level of medical education. Their main help-seeking strategies were proactive, and centered on medical institutions as official pathways, but they were often unable to find the necessary resources. Some developed an individual understanding of health and control over health, but others neglected medical therapies, or experienced disappointment with care. Finally, there was a "disadvantaged" [sic] group comprising people from a rural area (in Aronson's investigation they were, without exception, Russian Germans). Their education was more practical (skilled and unskilled), and their networks were limited to access to institutionalized medical care. Medical knowledge was considered the domain of women; women allocated health and medical resources, proactively sought medical information, and made choices about nutrition (Aronson, 2011a). In this group, a doctor was consulted only when disease was severe (Wittig, Merbach, 2004).

\section{Personal resources}

Cockerham describes the so called "Homo sovieticus" (Sinowjew, 1978) created by the totalitarian system of the Soviet Union. Characteristics of this type of person were a negative lifestyle, including alcoholism, excessive cigarette smoking, infrequent use of healthcare, and other health-risk behaviours (Cockerham, Snead, Dewaal, 2002).

Aronson contradicts the generalization of "homo sovieticus" as being passive, particularly in relation to healthcare. Jewish immigrants tend to have a high level of education, come from urban areas, and consciously separate themselves from the perceived "uncultured" lifestyle of the people of their country of origin. Their knowledge of alternative medicine was similar to that of their country of origin, although related literature was difficult to obtain (Aronson, 2011a). However, people with high levels of education who were formerly disadvantaged, and later empowered, tended to conceptualize and adapt their individual behavior (Aronson, 2011a, 2011b). Being self-motivated, and showing an optimistic attitude, were perceived as positive ways of coping (Barko et al., 2011).

Another study found that women from Ukraine, Russia, and Kazakhstan (referred to as "Slavic immigrants"), reported adopting a controlled diet with less fat and sugar, and more fruit and vegetables; which was a change to their previous diet. However, this study had several limitations, as it used a convenience sample, and questions were directly related to diabetes education. It might be possible that participants simply repeated the content of counseling, rather than their own behavior. In addition, the study only included women (Shultz, Corbett, Allen, 2009).

Most repatriates came from rural areas, and were less well-educated because of the environment of political stigma and discrimination. Their understanding of survival in a restrictive system was conceptualized as "home-grown vegetables", and "harvesting and eating together" (Aronson, 2011b). Two of the selected studies noted that repatriates perceived the German healthcare system as a great opportunity to 
restore their health (Kirkcaldy et al., 2005, 2007). However, both articles reported on the same investigation and study participants.

\section{Social environment}

Barko et al. reported on barriers to diabetes control for Russian-speaking immigrants in the Unites States, including low formal levels of education, low income, and poor self-management skills. They described this as a problem for under-insured people in the United States (Barko et al., 2011). Social and financial burdens were also described in successor states of the former Soviet Union. Care was highly medicalized, and high formal and informal costs were reported, with patients paying for glucose meters, test strips, and needles. Physicians were also overburdened, with little time available to spend with patients. No evidence was found of regular counseling on dietary or psychological needs. Barriers to continuous healthcare were geographical (urban or rural region) and/or financial. Patients reported "relying on themselves" rather than their physicians. Some patients sought alternative treatments because of a lack of success of therapies (Kühlbrandt et al., 2014).

Children and grandchildren also played a dominant role in the comments of interviewed participants in some studies. A major concern for study participants was being active in any form. Important sources of support were participants' families, Jewish and Christian communities, and municipalities (Brua, Johnson, 2011; Purath et al., 2011; Simolka, 2011). After moving to Germany, the majority of repatriates lived in multi-person households. The number of family members per household was significantly higher than in the average German population (Wittig et al., 2003), (Worbs et al., 2013). In addition, family members of ethnic German repatriates tended to live nearby, even years after immigrating (Wittig et al., 2003).

Table 4 Detailed list and description of the focus of each study: Russian Germans (issue without diabetes but in context of subjective health theories)

\begin{tabular}{|c|c|c|c|c|c|c|}
\hline $\begin{array}{l}\text { Author } \\
\text { Date } \\
\end{array}$ & Title & Country & Publication & Methodology & Participants & $\begin{array}{l}\text { Main research } \\
\text { question }\end{array}$ \\
\hline $\begin{array}{l}\text { Wittig et al. } \\
2003\end{array}$ & $\begin{array}{l}\text { Der Einfluss der } \\
\text { Familie auf die } \\
\text { Krankheitsverarbeit } \\
\text { ung bei } \\
\text { Spätaussiederinnen }\end{array}$ & Germany & $\begin{array}{l}\text { In: Gut } \\
\text { versorgt? } \\
\text { Migrantinnen } \\
\text { und Migranten } \\
\text { im Gesundheits- } \\
\text { und } \\
\text { Sozialwesen } \\
\text { (Book) }\end{array}$ & $\begin{array}{l}\text { qualitative- } \\
\text { descriptive } \\
\text { socio- } \\
\text { demographic } \\
\text { questionnaire, } \\
\text { guided } \\
\text { interviews }\end{array}$ & $\begin{array}{l}\text { married couples, } \\
\text { bi-national } \\
(\mathrm{n}=30)\end{array}$ & $\begin{array}{l}\text { health belief in } \\
\text { the family, } \\
\text { locus of control }\end{array}$ \\
\hline $\begin{array}{l}\text { Kirkcaldy et } \\
\text { al. } \\
2005\end{array}$ & $\begin{array}{l}\text { Health and } \\
\text { emigration: } \\
\text { Subjective } \\
\text { evaluation of health } \\
\text { status and physical } \\
\text { symptoms in } \\
\text { Russian-speaking } \\
\text { migrants }\end{array}$ & Germany & $\begin{array}{l}\text { Stress and } \\
\text { Health }\end{array}$ & $\begin{array}{l}\text { longitudinal } \\
\text { study, Giessen } \\
\text { Subjective } \\
\text { Complaints } \\
\text { List-24 } \\
\text { questionnaire }\end{array}$ & $\begin{array}{l}\text { Russian- } \\
\text { speaking } \\
\text { migrants/ethnic } \\
\text { German } \\
\text { repatriates } \\
(\mathrm{n}=307) \\
\text { compared with } \\
\text { Russians in } \\
\text { Russia }(\mathrm{n}=300) \\
\text { and native } \\
\text { Germans } \\
(\mathrm{n}=310)\end{array}$ & $\begin{array}{l}\text { to explore self- } \\
\text { reported health } \\
\text { status and } \\
\text { physical } \\
\text { symptoms }\end{array}$ \\
\hline $\begin{array}{l}\text { Kirkcaldy et } \\
\text { al. } \\
2007\end{array}$ & $\begin{array}{l}\text { A comparison of } \\
\text { general and illness- } \\
\text { related locus of } \\
\text { control in Russians, } \\
\text { ethnic German } \\
\text { migrants and } \\
\text { Germans }\end{array}$ & Germany & $\begin{array}{l}\text { Psychology, } \\
\text { Health and } \\
\text { Medicine }\end{array}$ & $\begin{array}{l}\text { questionnaires, } \\
\text { "Multidimensio } \\
\text { nal Health } \\
\text { Locus of } \\
\text { Control", } \\
\text { "Illness-related } \\
\text { Locus of } \\
\text { Control" } \\
\text { univariate and } \\
\text { multivariate } \\
\text { data analyses }\end{array}$ & $\begin{array}{l}\text { Russian } \\
\text { Germans/ ethnic } \\
\text { German } \\
\text { repatriates ( } \mathrm{n}= \\
307) \\
\text { native Russians } \\
\text { (in Russia) }(\mathrm{n}= \\
300) \\
\text { native Germans } \\
(\mathrm{n}=100)\end{array}$ & $\begin{array}{l}\text { general and } \\
\text { illness-related } \\
\text { locus of control }\end{array}$ \\
\hline
\end{tabular}




\section{Recommendations for diabetes mellitus counseling}

The selected studies suggest that conversations should always be conducted in Russian. Ideally, the supervising therapist should be fluent in Russian. Counseling provided by Russian-born therapists is reported to constitute a key element of therapeutic access (Shultz et al., 2009), and if this is not possible, interpreters with medical knowledge are required.

A "good doctor" was characterized by a high level of professional competence and understanding of the perceptions of their patients in terms of the complexity of health treatments, and their living conditions (Simolka, 2011). Immigrants were also reported to regard the unfamiliar healthcare system as confusing (Mayer, Becker, 2011; Simolka, 2011; Van Son, Gileff, 2013). Therefore, an explanation of the German health and welfare system was a favored topic for possible training programs (Simolka, 2011).

Some studies highlighted a marked lack of medical knowledge among Russian-speaking immigrants (Barko et al., 2011; Brua, Johnson, 2011). Repetition of explanations about medical background was indispensable in therapy compliance (Van Son, Gileff, 2013). However, this depended on the immigrants' current level of education and socioeconomic status.

Other studies described low adherence to prescribed medications in Russian-speaking participants (Barko et al., 2011; Brua, Johnson, 2011). They tended to change the frequency of intake, quantity, and strength of medications, according to availability, their own conceptions of the efficacy of therapies. Therefore, interactions between medications and the role of medication management should be repeatedly emphasized (Barko et al., 2011; Brua, Johnson, 2011; Simolka, 2011).

Many studies noted that some alternative medicines had been prescribed by doctors (homeopathy and natural therapies) in the former Soviet Union (Barko et al., 2011; Ben-Arye et al., 2011; Brua, Johnson, 2011; Simolka, 2011; Van Son, 2007; Van Son, Stasyuk, 2014). Participants in these studies labeled the use of these remedies as "just healthier-gathering, growing, giving" (Van Son, 2007). This suggests that healthcare providers require some degree of knowledge about herbal medicines traditionally used by Russian-speaking immigrants. Barko et al. (2011) recommended that doctors be non-judgmental with respect to these alternative therapy methods, and include them in their patient counseling, as patients may therefore be more willing to discuss other therapies. Van Son et al. (Van Son, Stasyuk, 2014) noted the importance of brief, literature-based information about commonly-used complementary medicine, herbal foods, and remedies. They described popular beliefs in Slavic communities regarding complementary medicine, along with potential negative outcomes and dangers.

Other studies insisted that physical activity should be seen as part of daily life. Participants in these studies reportedly expected benefits such as maintenance of health and physical independence (Purath et al., 2011). However, another study emphasized that repatriates defined "health" as "being able to work" (Aronson, 2011b). This definition differs from the definition of the World Health Organization (World Health Organization, 2014), and has other consequences.

The stress of immigration was seen as a trigger for diabetes mellitus (Simolka, 2011). Jewish study participants were in need of the activation of internal resources regarding the normalization of blood glucose levels, psychological support, and stability (Simolka, 2011).

The selected studies noted that consultations should take place in environments acceptable to immigrants, such as the usual meeting places of Russian-speaking immigrants. Such environments represent a protected area of shared social and communicative rules, in the cultural context of the affected people (Kofahl, Hollmann, Möller-Bock, 2009).

The cultural beliefs and behaviors of Russianspeaking immigrants may influence their ability to make changes in daily physical activities or adopt a healthy diet when they are affected by diabetes mellitus type 2. Van Son (2014) described a project in which culturally targeted educational diabetes documents were developed, designed, and piloted. Such materials may help healthcare providers in counseling older Russian-speaking people regarding diabetes self-management behaviors.

Although Ben-Arye et al. (2011) did not focus on diabetes, they described an association between selfreported religiosity and the use of complementary medicine (e.g., alternative medicine, traditional Chinese medicine, massage).

\section{Discussion}

It is difficult to represent the complex diversity of nationalities of immigrants from the former Soviet Union. The authors of most of the selected studies did not describe their participants' relationship to their living environment, socialization, education, ethnic backgrounds, and reasons for immigration. However, Aronson did give an important hint. She discussed the social context of immigrants from the former Soviet Union in terms of health beliefs, help- 
seeking, and perceptions of health and nutrition (Aronson, 2011a, 2011b). In their model of social inequality of health, Richter and Hurrelmann (2007) described the impact of socioeconomic status and education level on psycho-social factors, behavior, and health. Other studies reported that Jewish immigrants mainly came from urban areas, were well qualified, and showed a high degree of assimilation in both the former Soviet Union and Germany (Aronson, 2011b; Kessler, 2003; Simolka, 2011). These immigrants equated an unhealthy lifestyle with an "uncultured" lifestyle, and associated healthy nutrition with "rich Germans" because of their high socioeconomic status. They indicated that they would like to adopt this diet, and deliberately distanced themselves from the lifestyle of their country of origin (Aronson, 2011b).

The lives of German immigrants from the former Soviet Union were characterized by the experience of destitution in extreme situations, restrictive political curtailment of educational opportunities, and stigmatization because of their Christian faith. Survival was only possible through solidarity within the family. Producing everything themselves (growing, harvesting, and cooking using traditional family recipes) required the active involvement of all family members, and relied on their continuing good health, and eating together as a family (Aronson, 2011b). This was referred to as the "we as a family" identity by Schnepp (2002). Knowledge of health, disease, and healthy nutrition was considered "women's knowledge" (Wittig, Merbach, 2004; Aronson, 2011b). However, this was also due to a lack of medical care in the rural areas where Russian Germans lived. Repatriates showed a more highly internalized locus of control compared with native Germans (Kirkcaldy et al., 2007). They felt confident about the influence of personal factors (social learning theory based on Rotter) (Rotter, 1966), and assumed responsibility for their health (Kirkcaldy et al., 2007). Their powerful social networks, improved quality of life, and the better healthcare available in Germany might explain the lower mortality rate (including suicide) of repatriates compared with the original populations of former Soviet Union countries (Kyobutungi et al., 2006). The influence of the extended family on repatriates' feeling of being at home in Germany should not be underestimated (Wittig et al., 2003; Wittig, Merbach, 2004). This "lay healthcare system" (family and friends) is an additional resource. Jewish immigrants also considered family ties to be one of their most important motivators (Brod et al., 1992; Borovoy, Hine, 2008; Simolka, 2011).
Jewish communities offer extensive social networks, with professional social workers, and a wellstructured system of lay volunteers. These resources were also available for their Russian-speaking family members, and can be used for counseling on disease management for diabetes mellitus.

In the successor states of the former Soviet Union, patient experiences included the significant financial burden of the cost of diabetes treatment. The problems of the healthcare system in the country of origin are manifold, and include issues related to infrastructure, education, healthcare professionals, social-cultural factors, economic factors, and political factors (Weinhold, Gurtner, 2014). To ensure people receive high-quality care, concerted effort is required. However, this may only be possible in urban regions, in private clinics, and by out-of-pocket payments (Kühlbrandt et al., 2012).

For successful counseling, Mayer and Becker recommended sufficient time (patience), openness, understanding, and possession of background knowledge by the therapist (Mayer, Becker, 2011). Healthcare professionals require specific training in cultural competence and communication for both Russian-speaking immigrants and Russian Germans. The aim of their article is a short description of historical reasons for and effects of immigration from the former Soviet Union. They sought to clarify healthcare professionals' understanding of the situations of Russian-speaking immigrants (Becker et al., 2016).

\section{Conclusion}

The culturally-specific differences in Russianspeaking immigrants and Russian Germans from the former Soviet Union, as well as their background characteristics, may be relevant in the management of chronic diseases. In addition, the complex heterogeneity of the groups of immigrants from the former Soviet Union is difficult to describe.

In the present literature review, few general references to the subjective experience of illness, and personal resources of Russian-speaking immigrants and Russian Germans were found. Further research is required to inform useful counseling strategies for Russian-speaking immigrants and Russian Germans affected by diabetes mellitus.

Zielke-Nadkarni (2006) speaks of the "internal logic of subjective world pictures", which should be individually interpreted and used in counseling with immigrants. Understanding this mindset may also open up new approaches to helpful advice and resources. 
Leventhal, Diefenbach and Leventhal (1992) and Kleinman and Benson (2006) described cultural competencies for healthcare providers that are necessary for the counseling of immigrants in general. Leventhal Diefenbach and Leventhal (1992) (presented a model and targets for coping, with better adherence to medical therapies, focusing on a reduction of symptoms, and expectancy of change with time. Kleinman and Benson (2006) described eight easy steps and questions to use in alteringimmigrants' perception of therapies in an explanatory model.

The present article invites further discussion on the theme of counseling Russian-speaking immigrants and repatriates affected by diabetes mellitus. The authors are interested in the knowledge to be gained from such discussions, and hope to stimulate this debate.

\section{Limitation of the study}

Only publications in English and German were incorporated into this review.

\section{Ethical aspects and conflict of interest}

This research received no specific grant from any funding agencies in the public, commercial, or nonprofit sectors. The authors have disclosed any financial and personal relationships with other persons or organizations that could inappropriately influence their work.

The University of Witten/Herdecke (Germany) Institutional Research Review Board approved this study.

\section{Author contribution}

SS conceived the study, carried out the data extraction and analysis, and drafted and edited the final manuscript. WS conceived the study, participated in its design, revised the manuscript critically for important intellectual content, and helped to edit the final draft. Both authors read and approved the final version of the manuscript.

\section{References}

Antonovsky A. Salutogenese: Zur Entmystifizierung der Gesundheit. 1st ed. Deutsche Gesellschaft für Verhaltenstherapie, Tübingen; 1997. (in German)

Aronson P. Health beliefs and help-seeking practices of migrants from the former USSR into Germany. Warwick: University of Warwick, Department of Sociology; 2011a [cited 2015 Dez 24]. Avialable from: http://wrap.warwick.ac.uk/50831/1/WRAP_THESIS_Aronso n_2011.pdf

Aronson P. The salad of ideas: beliefs about health and food among immigrants from the former USSR in Germany.
Cargo. Journal of Cutural and Social Anthropolgy. 2011b;9(1-2):51-72.

Bandura A. Self-efficacy: Toward a Unifying Theory of Behavioral Change. Psychological Review. 1977;84(2):191215.

Barko R, Corbett CF, Allen CB, Shultz JA. Perceptions of diabetes symptoms and self-management strategies: a crosscultural comparison. Journal of Transcultural Nursing: Official Journal of the Transcultural Nursing Society / Transcultural Nursing Society. 2011;22(3):274-281.

Becker I, Mayer O, Ernst M, Seger W. Anforderungen an eine professionelle interkulturelle Kompetenz der Beschäftigten im Gesundheitswesen. Gesundheits- und Sozialpolitik. 2016;70(3):59-66. (in German)

Ben-Arye E, Schiff E, Karkabi K, Keshet Y, Lev E. Exploring association of spiritual perspectives with complementary medicine use among patients with Type 2 diabetes in Israel. Ethnicity \& Health. 2011;16(1):1-10.

Borovoy A, Hine J. Managing the unmanageable: elderly Russian Jewish émigrés and the biomedical culture of diabetes care. Medical Anthropology Quarterly. 2008;22(1):1-26.

Brod M, Heurtin-Roberts S. Older Russian emigres and medical care. The Western Journal of Medicine. 1992;157(3):333-336.

Brua CR, Johnson K. Health-care access in a rural area: perspectives from Russian-speaking immigrants, Englishspeaking doctors, and volunteer interpreters. Pennsylvania: The Pennsylvania State University, The Graduate School, Department of Applied Linguistics; 2011 [cited 2013 Oct 06]. Avialable from: https://etda.libraries.psu.edu/paper/9818/ Bundesamt für Migration und Flüchtlinge. Migrationsbericht des Bundesamtes für Migration und Flüchtlinge im Auftrag der Bundesregierung (Migrationsbericht 2013). Germany: Berlin; 2013. (in German)

Bundesministerium der Justiz. Gesetz über die Angelegenheiten der Vertriebenen und Flüchtlinge (Bundesvertriebenengesetz-BVFG). Germany: Berlin; 2013 [cited 2016 Sep 04]. Avialable from: http://www.gesetze-iminternet.de/bvfg/index.html (in German)

Bundesministerium des Inneren. Anordnung des Bundesministeriums des Innern gemä $\beta$ \& 23 Abs. 2 des Aufenthaltsgesetzes über die Aufnahme jüdischer Zuwanderer aus der ehemaligen Sowjetunion mit Ausnahme der Baltischen Staaten vom 24. Mai 2007 (zuletzt geändert: 13. Januar 2015, in der Fassung vom 21. Mai 2015). Germany: Berlin; 2015:1-5 [cited 2016 Sep 09]. Avialable from: http://www.bamf.de/SharedDocs/Anlagen/DE/Downloads/Inf othek/JuedischeZuwanderer/anordnung-bmi.html (in German) Bundeszentrale für politische Bildung. Zuzug von (Spät-) Aussiedlern und ihren Familienangehörigen. 2012 [cited 2016 Sep 03]. Avialable from: http://www.bpb.de/nachschlagen/zahlen-und-fakten/sozialesituation-in-deutschland/61643/aussiedler (in German) Cockerham WC, Snead MC, Dewaal DF. Health lifestyles in Russia and the socialist heritage. Source Journal of Health and Social Behavior. 2002;43(1):42-55.

Franke A. Modelle von Gesundheit und Krankheit. 1st ed. Bern: Verlag Hans Huber; 2008. (in German)

Hosler AS, Melnik TA, Spence MM. Diabetes and its related risk factors among Russian-speaking immigrants in New York State. Ethnicity \& Disease. 2004;14(3):372-377. PubMed: https://www.ncbi.nlm.nih.gov/pubmed/15328938 International Diabetes Federation. IDF Diabetes Atlas 2015. 
7th ed. Brussels: International Diabetes Federation; 2015 [cited 2016 Sep 18]. Avialable from: http://www.diabetesatlas.org/

Kessler J. Jüdische Migration aus der ehemaligen Sowjetunion seit 1990. Germany: Berlin; 2003 [cited 2016 Oct 28]. Avialable from: http://berlinjudentum.de/gemeinde/migration-1.htm (in German)

Kirkcaldy BD, Siefen RG, Merbach M, Rutow N, Brähler E, Wittig U. A comparison of general and illness-related locus of control in Russians, ethnic German migrants and Germans. Psychology, Health and Medicine. 2007;12(3):364-379.

Kirkcaldy BD, Siefen RG, Wittig U, Schüller A, Brähler E, Merbach M. Health and emigration: Subjective evaluation of health status and physical symptoms in Russian - Speaking migrants. Stress and Health. 2005;21(5):295-309.

Kleinman A, Benson P. Anthropology in the clinic: the problem of cultural competency and how to fix it. PLoS Medicine. 2006;3(10):e294.

Kofahl C, Hollmann J, Möller-Bock B. Gesundheitsbezogene Selbsthilfe bei Menschen mit Migrationshintergrund. Bundesgesundheitsblatt, Gesundheitsforschung, Gesundheitsschutz. 2009;52(1):55-63. (in German)

Kühlbrandt C, Balabanova D, Chikovani I, Petrosyan V, Kizilova K, Ivaniuto O, Danii O, Makarova N, McKee M. In search of patient-centred care in middle income countries: the experience of diabetes care in the former Soviet Union. Health Policy. 2014;118(2):193-200.

Kühlbrandt C, Basu S, McKee M, Stuckler D. Looking at the Russian health care system: through the eyes of patients with diabetes and their physicians. The British Journal of Diabetes \& Vascular Disease. 2012;12(4):181-184.

Kyobutungi C, Ronellenfitsch U, Razum O, Becher $\mathrm{H}$. Mortality from external causes among ethnic German immigrants from former Soviet Union countries, in Germany. European Journal of Public Health. 2006;16(4):376-382.

Leventhal H, Diefenbach M, Leventhal EA. Illness cognition: using common sense to understand treatment adherence and affect cognition interactions. Cognitive Therapy and Research. 1992;16(2):143-163.

Mayer O, Becker I. Pflegeberatung bei russischsprachigen Migranten aus der Gemeinschaft der unabhängigen Staaten (GUS): Empfehlungen am Beispiel des Pflegestützpunktes Berliner Freiheit. 1st ed. Hamburg: Diplomica Verlag GmbH; 2011. (in German)

Pasumansky N. Predisposition to Non-insulin-dependent diabetes mellitus among immigrants from the former Soviet Union. In: de Chesnay M, Anderson, BA, editors. Caring for the vulnerable - perspectives in nursing theory, practice and research. 3rd ed. London: Jones \& Bartlett Learning; 2012. p. 289-302.

Purath J, Van Son C, Corbett CF. Physical activity: exploring views of older Russian-speaking Slavic immigrants. Nursing Research and Practice. 2011;2011:507829.

Richter M, Hurrelmann K. Warum die gesellschaftlichen Verhältnisse krank machen. In: Aus Politk und Zeitgeschehen. Bundeszentrale für politsche Bildung; Bonn, Frankfurt am Main; 2007;42:1-40 [cited 2013 Dec 12]. Avialable from: http://www.bpb.de/apuz/30176/warum-die-gesellschaftlichenverhaeltnisse-krank-machen?p=all (in German)

Rotter JB. Generalized expectancies for internal versus external control of reinforcement. Psychological Monographs: General and Applied. 1966;80(1):1-28.

Schnepp W. Familiale Sorge in der Gruppe der russlanddeutschen Spätaussiedler. Bern: Verlag Hans Huber,
Hogrefe AG; 2002. (in German)

Schwarzer R. Psychologie des Gesundheitsverhaltens Einführung in die Gesundheitspsychologie. 3rd ed. Göttingen: Hogrefe Verlag; 2004. (in German)

Shultz JA, Corbett CF, Allen CB. Slavic women's understanding of diabetes dietary self-management and reported dietary behaviors. Journal of Immigrant and Minority Health. 2009;11(5):400-405.

Simolka S. Diabetes mellitus bei jüdischen Zuwanderern in Sachsen und Sachsen-Anhalt: subjektives Krankheitserleben und persönliche Ressourcen in der Krankheitsbewältigung Empfehlungen hinsichtlich Veränderungen der Beratungssituationen. 1st ed. München: Akademische Verlagsgemeinschaft; 2011. (in German)

Sinowjew A. Homo sovieticus. Zürich: Diogenes Verlag; 1978. (in German)

Statistisches Bundesamt. Ausländische Bevölkerung am 31.12.2011 nach Staatsangehörigkeit und aufenthaltsrechtlichem Status. In: Bevölkerung und Erwerbstätigkeit - Vorläufige Ergebnisse der Bevölkerungsfortschreibung auf Grundlage des Zensus 2011. Statistisches Bundesamt Wiesbaden; 2012. p. 79-88 (in German)

Stumpp K, Markstädter E, Kossko N, Fiebich A, Hagin M, Wiens H. Volk auf dem Weg - Deutsche in Russland und in der Sowjetunion 1763-1986. Eine kurze Übersicht. 3rd ed. Stuttgart: Kulturrat der Deutschen aus Russland e.V., Landsmannschaft der Deutschen aus Russland e.V.; 1986. (in German)

Tempel S. Zwischen Integration und Diskriminierung. Jüdische Allgemeine. 2006;6(12) [cited 2016 Jun 06]. Avialable from: http://www.zentralratdjuden.de/de/article/1175.zwischenintegration-und-diskriminierung.html (in German)

Tong A, Flemming K, McInnes E, Oliver S, Craig J. Enhancing transparency in reporting the synthesis of qualitative research: ENTREQ. BMC Medical Research Methodology. 2012;12:181-189.

Tselmin S, Korenblum W, Reimann M, Bornstein SR, Schwarz PE. The health status of Russian-speaking immigrants in Germany. Hormone and Metabolic Research. 2007;39(12):858-861.

Van Son CR. Ethnomedicine use by older adults from a Slavic community. Communicating Nursing Research. 2007;40:97-102.

Van Son CR, Gileff TY. Relying on what they know: older Slavic emigres managing chronic health conditions. Qualitative Health Research. 2013;23(12):1660-1671.

Van Son CR. Developing culturally targeted diabetes educational materials for older Russian-speaking immigrants. The Diabetes Educator. 2014;40(4):418-426.

Van Son CR, Stasyuk O. Older immigrants from the former Soviet Union and their use of complementary and alternative medicine. Geriatric Nursing. New York. 2014;35(2 Suppl):S45-S48.

Weinhold I, Gurtner S. Understanding shortages of sufficient healthcare in rural areas. Health Policy. 2014;118(2):201214.

Wittig U, Merbach M, Siefen R, Brähler E. Der Einfluss der Familie auf die Krankheitsverarbeitung bei Spätaussiedler/innen. In: Gut versorgt? Migrantinnen und Migranten im Gesundheits - und Sozialwesen. Frankfurt am Main: Mabus-Verlag; 2003. p. 191-202. (in German) Wittig U, Merbach M. Beschwerden und Inanspruchnahme 
des Gesundheitswesens von Spätaussiedlern bei Einreise nach Deutschland. Das Gesundheitswesen. 2004;66(2):85-92. (in German)

Worbs S, Bund E, Kohls M, Babka von Gostomski C. Familienstand und Lebensformen. In: (Spät-)Aussiedler in Deutschland - Eine Analyse aktueller Daten und Forschungsergebnisse. Bundesamt für Migration und Flüchtlinge, Nürnberg; 2013. p. 42-44. (in German)
World Health Organization. Consitution of the World Health Organization. In Basic Documents. 48th ed. Geneva: WHO Library Cataloguing in Publication Data; 2014. p. 1-20.

Zielke-Nadkarni A. Bedürfnisse individuell erfassen: Der Pflegeprozess - ein Instrument zur Versorgung von Migranten. Pflegezeitschrift. 2006;59(4):211-214. (in German) 